\title{
GRACILIANO RAMOS E SUAS MEMÓRIAS DO CÁRCERE: CICATRIZES
}

O artigo analisa alguns aspectos das Memórias do cárcere, de Graciliano Ramos, publicadas postumamente em I953. A questão principal diz respeito a uma certa ambiguidade envolvida na obra: a intenção expressa de registrar as arbitrariedades praticadas na cadeia também serviu para a distinção do autor, guindando-o ao pleno reconhecimento público como escritor e exemplo de intelectual vitimado pelo autoritarismo. ${ }^{\mathrm{I}}$

Procura-se dialogar implicitamente com uma proposta metodológica de Gustavo Sorá, ${ }^{2}$ para quem a análise de memórias envolve compreender as inter-relações da obra em si com a edição do livro, o autor e seu público, destacando também a importância da questão do passado visto do presente, bem como a circulação nacional e internacional do autor e da obra. Ainda que de modo sintético, esses aspectos serão abordados a seguir.

\section{A TRAJETÓRIA DE GRACILIANO RAMOS E SUA PRISÃo}

Memórias do cárcere, livro póstumo de Graciliano Ramos (I892-I953), tornou-se um clássico logo após sua edição, em I953. Quando o escritor faleceu, a obra já estava quase completa, só faltava a tarefa, sempre postergada, de redigir o capítulo final sobre o reencontro com a liberdade que havia se dado em I937, após mais de dez meses de prisão. Como o título ainda estava indefinido, os herdeiros e o editor decidiram-se por uma das possibilidades aventadas: Me- 
mórias do cárcere. Foram publicadas em quatro volumes pela editora José Olympio, a mais importante da época. ${ }^{3}$ Graciliano Ramos foi incentivado a escrever o texto pelo próprio Olympio, seu amigo, dono da célebre livraria que Graciliano frequentava com regularidade no centro do Rio de Janeiro, local de encontro de escritores, intelectuais e políticos. O editor pagava antecipadamente pelos direitos autorais, mediante a entrega de trechos dos originais. A necessidade de escrever às pressas para ganhar dinheiro, contudo, incomodava o autor perfeccionista, pois podia influenciar na qualidade de seus escritos (Ramos, 2008: 97, 260-26I). Apesar dos atrasos frequentes, ele cumpriu o tratado com Olympio. ${ }^{4}$

Foi o primeiro sucesso de vendas do "velho Graça", como ficou conhecido o escritor já renomado, mas até então pouco lido por um público mais amplo. Dez mil exemplares esgotaram-se em 45 dias, segundo Dênis de Moraes (1996: 310). ${ }^{5}$ Vários fatores colaboraram para o êxito da edição, tais como as lembranças das masmorras do primeiro governo Vargas, então em seu segundo governo e sofrendo forte oposição; ${ }^{6}$ a receptividade de setores antivarguistas da imprensa, da intelectualidade e também daqueles predispostos a exorcizar os fantasmas de colaboração com o Estado Novo; a perseguição a um artista célebre e injustiçado; o fato de ser um livro póstumo com as memórias polêmicas de autor recentemente falecido; os rumores em torno das críticas à obra no interior do Partido Comunista; além da notória qualidade literária do texto. O editor José Olympio soube usar esses fatores para o sucesso da obra no mercado, que serviu também para estimular as vendas de novas edições dos livros anteriores do autor.

Graciliano Ramos já escrevera parte de suas memórias em Infância (I945). Tratava de sua meninice subjetivamente sofrida no interior do estado de Alagoas, onde se sentia oprimido pelos adultos, apesar de descender de uma família privilegiada. Seu avô foi senhor de engenho, depois arruinado. O pai era comerciante, dono da loja de tecidos Sincera, em Palmeira dos Índios. Graciliano viveu no Rio de Janeiro, então capital federal, por um breve período na juventude, de agosto de I9I4 a agosto de I9I5, trabalhando em jornais, sobretudo como revisor. Ainda não lograra a pretendida colocação de destaque no meio jornalístico quando a tragédia familiar da morte de três irmãos pela peste bubônica o levou a retornar a Palmeira dos Índios. Logo se casaria e ficaria com a loja do pai, antes de assumir postos públicos.

Apesar da fama de sujeito difícil, sem papas na língua, sabia cativar as pessoas, cultivar amizades e inserir-se em redes literárias, sociais e políticas, como sua trajetória atestaria. Por exemplo, ocupou vários cargos públicos por indicação de amigos, em Palmeira dos Índios, em Maceió e no Rio de Janeiro. Foi nomeado presidente da Junta Escolar de Palmeira dos Índios em 1926, indicado pela família Cavalcanti, aliada do governador Costa Rego. Logo se tornou prefeito da cidade (I928-I930), após eleição em que foi candidato úni- 
co pelo Partido Democrata, com a benção dos coronéis locais. Acabou chamado pelo governo para servir em Maceió. Na capital alagoana, entre i930 e I936, foi diretor da Imprensa Oficial, professor e diretor da Instrução Pública, responsável pela educação no estado. Lá conviveu com um seleto grupo de intelectuais e escritores nordestinos, entre os quais Rachel de Queiroz, José Lins do Rego, Aurélio Buarque de Hollanda, Jorge de Lima, Manoel Diegues Jr. e Alberto Passos Guimarães.

Graciliano Ramos estava no meio da vida adulta quando foi vítima da onda repressiva após o levante comunista de novembro de I935, embora sem qualquer envolvimento com ele. Permaneceu no cárcere de 3 de março de 1936 a I3 de janeiro de I937. Completou, na cadeia, 44 anos de idade. Viúvo do primeiro matrimônio, era casado pela segunda vez com Heloísa, com quem teve quatro filhos, além de outros quatro do enlace anterior. Usufruía da vida de ilustre intelectual e funcionário público em Maceió. Em suas próprias palavras, era um "pai de família, meio funcionário, meio literato" (Ramos, 2008: 29); um "rabiscador provinciano detestado na província, ignorado na metrópole" (Ramos, 2008: 77). Naquela altura, dificilmente teria disposição para a aventura de estabelecer-se sem emprego na capital federal, não tivesse sido levado pelas circunstâncias, no caso, sua inesperada prisão.

Nunca soube ao certo o motivo do encarceramento, não chegou a ser oficialmente processado, sequer interrogado. Talvez sua atuação invulgar no comando da educação pública alagoana tenha contribuído para gerar desafetos e denúncias anônimas que o levaram à prisão. Por exemplo, ele implantou concursos públicos e recusava-se a fazer nomeações e transferências de professores e funcionários por indicação política. Referiu-se, nas Memórias, à "sensaboria da rotina" em seu cargo público. Junto com sujeitos que considerava decentes, entrara numa "engrenagem" que "nos sujava", de um ensino que envolvia o "emburramento" das crianças para aceitar o domínio de "políticos safados e generais analfabetos". Era contra o ensino de "hinos idiotas", como o do estado natal, que em sua administração não era tocado nas escolas (Ramos, 2008: 20-2I).

Embora não fosse militante de esquerda na época de sua prisão, desejava "a morte do capitalismo e o fim da exploração" (Ramos, 2008: 99), e seus dois filhos mais velhos integravam a Juventude Comunista, com a aprovação do pai. Considerava-se "uma espécie de revolucionário, teórico e chinfrim", que encontrava no cárcere os "revolucionários de verdade" (Ramos, 2008: 5I).

Apesar de suas ideias anticapitalistas, ainda não pertencia ao Partido Comunista do Brasil (PCB), e não teve ligação com o levante de I935, nem com a Aliança Nacional Libertadora (ANL). Ao contrário, fora servidor público de governos comprometidos com a República Velha e continuou a servir após o movimento de I930, apesar de ter-se oposto a ele, o que lhe valera breve prisão por envolvimento numa escaramuça de resistência. Graciliano contou nas 
Memórias que Agildo Barata, de quem ficaria amigo, ria ao ouvi-lo narrar, no Pavilhão dos Primários, uma "proeza besta" ocorrida logo após o movimento de I930: "um piquete das forças revolucionárias de Agildo Barata agarrou-me no interior de Alagoas e fingiu querer fuzilar-me. [...] Alguns dias de reclusão, vários aborrecimentos" (Ramos, 2008: 474).

Ao ser aprisionado em 1936, Graciliano já era um escritor reconhecido no meio literário. Publicara dois romances importantes quando ainda morava em Alagoas: Caetés, e o clássico São Bernardo, além de ter concluído a redação de Angústia, que foi lançado enquanto estava no cárcere. Seus livros estavam disponíveis até mesmo nas bibliotecas da cadeia, onde eram pouco lidos, ao contrário das obras de autores como Jorge Amado (Ramos, 2008: 470).

A experiência da prisão foi um corte na vida de Graciliano: ele não se animaria a voltar, sequer de visita, ao estado natal de Alagoas, onde residira praticamente a vida toda: "nunca mais poria os pés naquela terra" (Ramos, 2008: II6). Estabeleceu-se no Rio de Janeiro, ali permaneceu até morrer, em 20 de março de I953, vítima da doença dos fumantes inveterados como ele, câncer no pulmão.

Seus dias no cárcere foram traumáticos; ainda preso, tratou de fazer anotações detalhadas e extensas do que testemunhava, pensando numa obra futura. Mas desfez-se delas por razões de segurança, de modo que suas vivências ficaram apenas na memória. Depois de solto, jamais deixou de ruminar o assunto e de fazer apontamentos a respeito. Por exemplo, em 1938, chegou a escrever uma carta irônica de protesto - jamais enviada - ao ditador Vargas.7 Só em 1946, após a redemocratização da sociedade brasileira, começou a escrever o livro de memórias. Então, ele já militava no PCB, ao qual aderira em 1945, mantendo-se membro até o fim da vida. Não se tratava de imposição partidária; ao contrário, havia restrições da direção sobre a obra, o que talvez ajude a explicar por que só foi publicada postumamente. Graciliano parecia não querer concluí-la, considerava que "provavelmente isto será produção póstuma, como convém a um livro de memórias” (Ramos, 2008: 13).

Após sair da prisão, em 1937, foi nomeado inspetor geral de ensino secundário do Rio de Janeiro, por indicação do poeta e amigo Carlos Drummond de Andrade, que era chefe de gabinete do ministro da Educação do governo Vargas. O cargo de inspetor de ensino era mal remunerado e de importância secundária, mas aqui já se revelava a ambiguidade da situação, que se expressava também no emprego de Graciliano na revista Cultura Política, órgão intelectual vinculado ao Departamento de Imprensa e Propaganda do Estado Novo varguista. O velho Graça atuava como revisor de textos e não tratava de assuntos diretamente políticos em suas crônicas na seção "Quadros e costumes do Nordeste", ${ }^{8}$ cujo tema se afinava com o projeto nacionalista então em curso, comum ao governo e a uma parcela expressiva da intelectualidade, empenhada em intervir na gestão da cultura e da educação nacional, embora 
às vezes crítica do autoritarismo, que por certo também tinha seus intelectuais orgânicos.

O regime, se não o próprio Vargas, reconheceram a injustiça da prisão, e não apenas ao oferecer emprego público a Graciliano: no aniversário de 50 anos do romancista, em I942, houve uma célebre homenagem no restaurante Lido, em Copacabana. Compareceram os principais escritores e intelectuais da época, a começar por Gustavo Capanema. O poderoso ministro da Educação e Saúde liderava um projeto de formação educativa do qual participaram vários artistas e intelectuais; havia uma "tênue linha divisória" a separar a ação educativa e cultural da "mobilização político-social e de propaganda" do regime (Bomeny et al., 2000: I04). "Em suma, o pacto entre os intelectuais e o poder compromete a ambos, sem que se possa decidir qual deles tirou maior proveito", nos termos de Adriana Coelho Florent (20II: II2).

A intrincada relação entre literatura e política na trajetória de Graciliano estava presente já na sua "descoberta" como escritor. Do Rio de Janeiro, o editor e literato Augusto Frederico Schmidt incentivou Graciliano Ramos a escrever e publicar, depois de ter lido seus criativos relatórios administrativos como prefeito de Palmeira dos Índios, reunidos postumamente no livro Viventes das Alagoas (1962).

A convivência de Graciliano Ramos com o regime varguista foi menos intensa que a de outros artistas e intelectuais que ocuparam postos mais importantes, mas não deixava de ser contraditória. O juízo negativo que sempre fez de Vargas, ao menos desde a revolução de I930, não foi impedimento para assumir postos públicos, assim como antes ocupara cargos por indicação da oligarquia alagoana, da qual também era crítico. Na época, a condição de intelectual em geral - e de escritor em particular - era carente de autonomia e geralmente vinculada ao aparelho de Estado, como já apontaram vários estudiosos do tema. ${ }^{9}$

\section{MEMÓRIAS DO CÁRCERE}

O livro divide-se em quatro partes, e cada qual compunha um volume na edição original. "Viagens", a primeira parte, narra a prisão em Maceió, as cadeias por onde Graciliano passou no Nordeste e sua terrível jornada no porão do navio Manaus, rumo ao Rio de Janeiro, na companhia de outros presos, como os militares revoltosos da insurreição de novembro de 1935, em Natal. Havia também passageiros comuns a bordo, até mesmo os que viajavam de primeira classe e olhavam entre indiferentes, curiosos e enojados aqueles que seguiam apinhados no porão. O ambiente era de fedor, calor e sujeira. $\mathrm{O}$ autor encontrava refúgio no cigarro e nas notas que escrevia sobre a experiência em curso. Praticamente não se alimentou no navio, recusava com nojo a comida, mesmo à custa da saúde. 
Na segunda parte, "Pavilhão dos Primários", Graciliano Ramos relatou sua estada em uma ala da Casa de Detenção no Rio de Janeiro. Lá conviveu com dezenas de presos políticos, em geral acusados de envolvimento com a ANL ou com o levante de I935, entre os quais muitos militares e dirigentes comunistas. Ali funcionava um coletivo que organizava o cotidiano dos presos políticos. Destacavam-se lideranças como a do comunista argentino Rodolfo Ghioldi e do oficial Agildo Barata. O maior incômodo nessa prisão eram os percevejos, combatidos com afinco, mas sem êxito, pelo coletivo, segundo o autor. Realizavam-se de jogos de xadrez a sessões espíritas, de cursos educativos a rodas de samba nas celas e no espaço coletivo nomeado "Praça Vermelha". Os presos preparavam até um noticiário noturno diário na "rádio libertadora": um locutor de voz possante transmitia também notícias internacionais, como o andamento da guerra civil espanhola.

A rotatividade dos presos, que circulavam de cadeia em cadeia, também era expressiva. No Pavilhão dos Primários corriam histórias de quem passara por presídios bem mais duros, como a temível colônia correcional Dois Rios, na Ilha Grande, para onde Graciliano acabaria sendo transferido. A terceira parte do livro, "Colônia correcional", trata de sua passagem pela Ilha Grande, onde novamente passava dias praticamente sem comer. Lá os presos políticos conviviam com toda sorte de presidiários comuns, em condições precárias e promíscuas. Graciliano relatou, por exemplo, sua amizade com meliantes como um certo Gaúcho, orgulhoso de seu profissionalismo como ladrão. Contou também de companheiros de saúde mais abalada que acabaram morrendo quase como indigentes, caminho que provavelmente seria o dele, não fosse transferido após cerca de um mês preso ali, graças à mobilização de amigos e parentes no Rio de Janeiro, notadamente do já célebre romancista José Lins do Rego. Talvez seja o trecho mais angustiante do livro, em que o autor narrou a sensação de aproximar-se da morte nas condições mais degradantes.

Na parte final, "Casa de Correção", o escritor comentou sua volta ao Rio de Janeiro, onde ficaria preso em novo local, reencontrando companheiros com quem convivera em outras prisões. Relatou episódios como a deportação de Olga Benário e Elisa Berger para a Alemanha nazista.

Individual e coletivo, recolhimento e solidariedade, estranhamento e identificação com os outros presos são aspectos que se entrelaçam indissoluvelmente nas Memórias do cárcere.

\section{A ESCRITA COMO EXPRESSÃO DE DIGNIDADE E DISTINÇÃO}

Escrever na cadeia foi não só um recurso para manter a dignidade do autor preso, registrando as arbitrariedades sofridas, mas também um meio de distinção social, pois o fato de escrever dava-lhe prestígio, distinguindo-o entre 
os encarcerados, sendo tratado com alguma deferência e privilégio em meio a um ambiente despersonalizado.

As Memórias do cárcere podem ser interpretadas como um testamento literário. O autor registrou seu intento de ser lembrado como uma pedra no caminho dos poderosos, uma voz dissonante do coro dos contentes, que incomodava não propriamente pela militância política, mas por afirmar sua autonomia de escritor, livre para criticar e expor as cicatrizes sociais. Graciliano Ramos relatava seu mal-estar não só em relação à experiência na cadeia, mas também com sua própria vida em meio à modernização da sociedade brasileira. Seu ato de escrever denunciava uma sociedade marcada por desigualdades enormes, a colocar ainda obstáculos à profissionalização e autonomia dos escritores como ele, mas que paradoxalmente ofereceria relativos privilégios a seus artistas e intelectuais.

Ao entrar na Casa de Detenção do Rio de Janeiro, em I936, chegando de longa e penosa viagem de navio na condição de preso político, Graciano Ramos submeteu-se a um interrogatório de rotina para preenchimento de dados cadastrais. Já começou embirrando: insistiu em declarar que não tinha nenhuma religião, apesar do conselho reiterado do policial-burocrata de plantão, para quem seria mais "conveniente" expressar alguma crença no quesito "religião" do questionário (Ramos, 2008: I75-I76). Afirmava desde logo suas convicções, seu deslocamento social, a disposição de assumir-se como "gauche na vida", a exemplo de muitos intelectuais de sua geração, geralmente oriundos de oligarquias rurais decadentes, no contexto de modernização da sociedade brasileira. ${ }^{\text {10 }}$

O autor não queria se "acanalhar", afirmando possuir um Deus, mesmo que isso fosse conveniente (Ramos, 2008: 176). Um verbo frequente nas Memórias era "acanalhar-se", no sentido de perder a honra, um risco especialmente para os presos. ${ }^{\text {II }}$ Ele buscava sempre "conservar a dignidade" (Ramos, 2008: 338). Sobreviver sem perder a honradez, eis um dilema em todo o livro para um homem portador de valores cavalheirescos, cioso de sua dignidade, que via ameaçada a cada instante na cadeia.

Em várias passagens, Graciliano comparou a situação dos presos à de animais vivendo em conjunto, como gado, formigas, cupins ou ratos. Ele nunca se conformou com a situação de viver em "curral como bichos" (Ramos, 2008: 379), nem com a coisificação dos presos: "formávamos juntos um acervo de trastes, valíamos tanto como as bagagens trazidas lá de baixo e as mercadorias a que nos misturávamos" (Ramos, 2008: I57). Como manter a dignidade numa situação dessas, sem se acanalhar? Como preservar a personalidade e distinguir-se da manada? A resposta de Graciliano foi a escrita, as notas infindáveis que tomava e das quais mais tarde viria a se livrar, ainda quando preso. Ele as escrevia com intensidade proporcional à degradação a que era submetido. Mecanismo de defesa da própria dignidade num ambien- 
te de despersonalização, animalização e coisificação das pessoas. Mas ao mesmo tempo revelava-se a consciência de que o ato de escrever traria relativos privilégios sociais, de distinção, o que atormentava o autor. É o que se depreende, por exemplo, de um episódio das Memórias.

No meio da viagem ao Rio de Janeiro que conduzia Graciliano preso no porão do navio Manaus, o padeiro ofereceu-lhe lugar em seu camarote, ao reparar que o escritor tomava "notas difíceis, sentado no caixão, enxergando mal na sombra densa, o nariz junto à folha, a valise sobre os joelhos servindo-me de escrivaninha" (Ramos, 2008: I5I). Por escrever, parecia pessoa distinta da massa de gente aglomerada no porão do navio. Ao conseguir conforto maior que o de seus companheiros que viajavam em condições abjetas, o autor sentiu-se envergonhado e confessou usar a vergonha como pretexto para parar de escrever, podia "dispensar aquele recurso".

Se a escrita foi um refúgio para a sobrevivência no porão do navio, recurso para manter a dignidade e registrar as arbitrariedades sofridas, não deixou de ser também uma forma de distinção social. Em várias passagens do livro, Graciliano notou que escrever gerava prestígio, distinguindo-o entre os presos, os guardas e os dirigentes de presídio, que por isso o tratavam com alguma deferência num ambiente desumanizado. A cadeia não deixava de ser um microcosmo da inserção contraditória do escritor numa sociedade como a brasileira.

O episódio e o conjunto do livro expressam bem o que Marshall Berman (I986) chamou em outro contexto de "cisão fáustica" do intelectual, inspirando-se em Fausto, o herói romântico alemão criado por Goethe no século XIX. O personagem - como tantos, por exemplo, na literatura russa e outras em países de desenvolvimento capitalista tardio e autoritário - seria existencialmente dilacerado pela consciência de ser portador de privilégios de uma cultura avançada numa sociedade atrasada, cindido pela tensão entre a modernidade e o subdesenvolvimento. Graciliano, originário das oligarquias agrárias nordestinas, revelava mal-estar semelhante nas Memórias.

A distinção como estratégia de diferenciação que estaria no cerne da vida social (Bourdieu, 2008 [1979]) ganha contornos inesperados na obra de um escritor comunista como Graciliano Ramos. A arte burguesa de se distinguir "naturalmente" pelo gosto, diferenciado da ostentação dos emergentes e da suposta vulgaridade das classes dominadas, não combinaria com as ideias e os ideais dos comunistas. Mas isso não impede que o problema da distinção esteja presente em suas vidas e obras, como as Memórias do cárcere.

Os comunistas, baseados na obra-prima de Marx (1867), apontam a coisificação das pessoas no capitalismo, o embrutecimento gerado pelo fetichismo da mercadoria, que tende a fazer tabula rasa das diferenças entre os indivíduos. Algo que se exacerbaria numa situação-limite de prisão como a vivida por Graciliano, que comparou a condição dos presos à de animais, explicitando sua coisificação em passagens já mencionadas. Assim, para os 
comunistas, não seria um problema a distinção, entendida num sentido amplo como a plena expressão diferenciada de cada indivíduo, a caminho de uma sociedade futura na qual "o livre desenvolvimento de cada um é condição para o livre desenvolvimento de todos" (Marx \& Engels, I996 [I848]: 87). Mas a situação ganha contornos contraditórios quando se pensa a distinção em sentido estrito, que envolve poder e privilégios, por exemplo, aos escritores, como no caso do tratamento diferenciado que Graciliano obteve no navio quando se percebeu que ele escrevia, ou nas homenagens que lhe prestaram depois de ter deixado a cadeia, sem contar os vários cargos públicos de confiança que ocupou ao longo da vida, inclusive durante o Estado Novo. O episódio da cicatriz no braço de um preso, tratado a seguir, também ajuda a pensar o tema da distinção do escritor.

\section{A TATUAGEM-CICATRIZ DO ESQUELETO: PASSADO E PRESENTE NAS MEMÓRIAS DO CÁRCERE}

Um aspecto a considerar em qualquer reconstituição da memória é como o autor retoma o passado no presente em que escreve. Já se sabe que Graciliano Ramos se livrou das notas que tomava compulsivamente no cárcere. Ele poderia ter buscado algum mecanismo de fazê-las chegar fora da prisão, mas preferiu destruí-las, com receio de que lhe fossem confiscadas ou pudessem comprometê-lo, se apanhadas pela polícia. Chegou a escrever que talvez tenha sido melhor assim, para não ficar preso às notas no momento bem posterior de redação das memórias. Afirmou que o julgamento sedimentado em seu presente não poderia ficar prisioneiro do passado, consciente de que estava elaborando o tema da ótica do tempo em que escreveu, não dos fatos vividos, ainda que pretendesse ser fiel a eles (Ramos, 2008: I4).

É certo que toda escritura memorialística seleciona aspectos do passado com base na vivência do presente. O autor admitia que as lembranças seriam subjetivas e portanto diversas para cada pessoa em diferentes momentos, mesmo dando a "impressão de realidade" (Ramos, 2008: 13). Assim, ficava livre para

andar para a esquerda e para a direita, saltar passagens desprovidas de interesse, passear, correr, voltar a lugares conhecidos. Omitirei acontecimentos essenciais ou mencioná-los-ei de relance, como se os enxergasse pelos vidros pequenos de um binóculo, ampliarei insignificâncias, repetilas-ei até cansar, se isso me parecer conveniente (Ramos, 2008: 14).

Mesmo consciente de que o tempo pregresso é reconstituído a partir do momento corrente, Graciliano fez um esforço significativo para narrar com objetividade cada detalhe da prisão, como se ainda estivesse lá. Por mais que revelasse memória prodigiosa, contudo, decorridos tantos anos, não teria como evitar até mesmo algum anacronismo. Por exemplo, ao recordar-se da 
agitação na cadeia por ocasião da entrega à Gestapo de Olga Benário Prestes e Elisa Berger, Graciliano afirmava: "Sentado na cama, pensei com horror em campos de concentração, fornos crematórios, câmaras de gases. Iriam a semelhante miséria?" (Ramos, 2008: 635). Provavelmente, o autor de fato tenha temido pelo destino das duas nas mãos dos alemães, mas não tinha como pensar em câmara de gás e fornos crematórios em 1936, pois só em I939 foi criado um programa de extermínio pelos nazistas. ${ }^{\mathrm{I} 2}$

Talvez um episódio do livro ajude a compreender a retomada pelo autor, no seu presente, da experiência passada no cárcere. Depois de responder ao questionário na Casa de Detenção do Rio de Janeiro, no qual fizera questão de declarar-se sem religião, Graciliano dirigiu-se à rouparia. Lá estava um preso comum, ajudante de serviço. Um detalhe no antebraço do prisioneiro chamou a atenção:

\begin{abstract}
Aí se percebia, tatuado, um esqueleto, ruína de esqueleto: crânio, costela, braços, espinha; medonha cicatriz, no pulso, havia comido a parte inferior da carcaça. Desejando livrar-se do estigma, o pobre causticara inutilmente a pele; sofrera dores horríveis e apenas eliminara pedaços da lúgubre figura. Não conseguiria iludir-se, voltar a ser pessoa comum. Os restos da infame tatuagem, a marca da ferida, iriam persegui-lo sempre; a fatiota desbotada conservava o sinal da tinta. Era-me impossível desviar os olhos da representação fúnebre. Em vão queria distrair-me. Tinha pena do infeliz e zangava-me (Ramos, 2008: 177).
\end{abstract}

Eis um aspecto fundamental do estilo literário de Graciliano Ramos: o gosto pelos detalhes, o desagrado com aqueles que liam seus livros "apreendendo a essência e largando o pormenor". Afinal, segundo ele, "são as minúcias que me prendem, fixo-me nelas, utilizo insignificâncias na construção das minhas histórias" (Ramos, 2008: 2I2). A aparente minúcia do episódio da tatuagem perdida num livro imenso seria plena de significado. ${ }^{13}$ A experiência do cárcere viria a cravar-se na memória e na vida de Graciliano Ramos como a tatuagem deformada no braço do detido, indestrutível, da qual o olhar não se despregava. Inútil tentar eliminar a cicatriz subjetiva, a marca da ferida iria persegui-lo para sempre. O cárcere seria um divisor de águas em sua vida. Levaria dez anos para começar a escrever a respeito, morreria sete anos depois de iniciar o trabalho, com a obra ainda inconclusa, sem a ilusão de que poderia "voltar a ser pessoa comum".

Quatro meses depois do primeiro encontro, Graciliano topou de novo com o preso de tatuagem no antebraço. Espantou-se ao ser saudado pelo rapaz, que o vira só uma vez. Como seria possível reconhecê-lo, distingui-lo, em meio a um grupo numeroso? Lembrou-se da conversa dos dois, de como o preso também era um homem que reparava em detalhes, o único que o percebeu inquieto apesar dos esforços para demonstrar calma. Afinal, ele notara que o autor mexera na valise que carregava "mais de vinte vezes, não achava lugar para colocá-la. Surpreendera-me ver alguém reparar em tais minúcias e tirar consequências justas" (Ramos, 2008: 366-367). 
Graciliano recordava-se da aflição do rapaz, prestes a ser solto, que não sabia para onde ir e o que fazer depois de libertar-se. Identificava-se com o preso, concluindo que o cárcere mudava o rumo de sua vida: "Para onde? Essas palavras tinham-me impressionado e não me cansava de repeti-las. Ao deixar a sala fazia a mim mesmo a pergunta do rapaz do esqueleto: - Para onde?" (Ramos, 2008: 367) Ele se lembraria da pergunta ao ser removido para a temível colônia correcional da Ilha Grande, sentindo-se o próprio esqueleto, como outros presos que vira regressar da Ilha Grande, "farrapos" (Ramos, 2008: 378).

O episódio expressava um jogo complexo de espelhamento entre o eu e o outro, o indivíduo e a sociedade, o passado e o presente. Cada personagem surpreendendo-se por encontrar no outro a marca da própria miséria, que ganhava também um sentido coletivo na situação adversa. A minúcia do caso permitiria pensá-lo metaforicamente ao menos por duas vias entrelaçadas: primeiro, a experiência passada no cárcere cravava-se subjetivamente no presente de Graciliano, indelével como a tatuagem-cicatriz no braço do rapaz, por mais que a quisesse apagar, deformando-a com soda cáustica. Segundo, o próprio autor poderia ser representado pela caveira tatuada, um farrapo humano, como outros presos. Uma carcaça que não deixava de ser marca de distinção, impossível de apagar, cujos traços ficariam expostos também para os outros que os veriam de fora, para uma sociedade que não se livraria, no presente, da mancha de tinta da morte no passado.

Em outros termos, é evidente que a experiência carcerária foi algo traumático, deixando cicatrizes no autor, num sentido metafórico. Mas há aspectos adicionais: a cicatriz do preso resultava de tentativa de apagar uma tatuagem, a metáfora iria além das marcas da prisão em Graciliano e seus companheiros de infortúnio. Eles mesmos se tornavam marcas incômodas no corpo social, que não podia se livrar delas. Isso leva ao aspecto da distinção moral daqueles que foram vítimas da repressão posterior ao levante comunista de I935, bem como dos intelectuais perseguidos, tendo Graciliano se tornado sua encarnação por excelência, embora não fosse militante na época e, depois de solto, tenha ocupado cargos ligados ao governo federal.

Outro possível elemento de distinção pode ser encontrado na busca do autor para a difusão nacional e internacional de sua obra, em contatos com seus editores no Brasil e na Argentina, que são mencionados de passagem ao longo das Memórias.

\section{MAIS “MINÚCIAS" E ELOS PERDIDOS}

Um aspecto pouco destacado em Memórias do cárcere, mas notável para quem buscar analisar o tema da circulação internacional de artistas e intelectuais, é a referência aos estrangeiros, como o editor argentino Benjamin de Garay. Ele traduziu alguns textos de Graciliano Ramos para o espanhol, o que rendia 
alguns poucos cobres, mas essenciais para o alagoano, sempre apertado de dinheiro (Ramos, 2008: 38). Garay trabalhara como jornalista no Brasil e mantinha contato com escritores. Em junho de I936, o conto "A testemunha", prometido por carta a Garay, saiu na revista El Hogar, de Buenos Aires. Ainda preso, Graciliano escreveu os contos "O relógio no hospital" e "Dois dedos", ambos logo enviados para tradução na Argentina, aos cuidados de Garay, que prometia articular na América Latina um movimento pela libertação de Graciliano. Logo depois de sair da cadeia, o autor enviou a Garay o conto "Baleia", embrião do romance Vidas secas. Seguiu em correspondência com o portenho por anos a fio, como relatou Dênis de Moraes (I996: I00, I30, I4O-I4I, 222).

Graciliano Ramos manteve relação com vários estrangeiros que estavam no cárcere, acusados de envolvimento com o levante de I935. Era o caso do líder comunista argentino Rodolfo Ghioldi, de quem se tornou muito amigo, e que lhe deu respaldo por ocasião da ida desesperada a Buenos Aires no fim da vida, para submeter-se a uma operação de câncer. O tratamento foi financiado pelo PCB, que já enviara o velho Graça - então presidente da Associação Brasileira de Escritores, controlada pelos comunistas - em viagem à União Soviética junto com outros artistas e intelectuais em 1952. Os escritos a respeito foram publicados, logo depois de sua morte, no livro Viagem (Ramos, 1954). As atribulações dessa viagem aparecem também nas obras biográficas já referidas. Havia desentendimentos tópicos de Graciliano Ramos com a direção do PCB. Como se sabe, ele era crítico do realismo socialista zdanovista e de aspectos da vida na União Soviética, mas foi um stalinista convicto. Ricardo Ramos (I992) contou que uma das raras vezes em que viu o pai chorar foi por ocasião da morte de Stálin.

A proximidade dos stalinistas não impediu a boa relação no cárcere com não-comunistas, até mesmo o russo Rafael Kamprad, conhecido como Serge, acusado de ser trotskista. Graciliano declarava-se internacionalista no livro, tratava com certo desdém os nacionalistas, especialmente a esquerda militar. Entretanto, o autor quase não teve obras traduzidas em vida, ao contrário de outros camaradas mais afinados com as diretrizes culturais oficiais do realismo socialista, como Jorge Amado (Ridenti, 20I I).

As Memórias do cárcere viraram um clássico, mas nem por isso se tornaram referência decisiva para dezenas de autores que relataram em livro - a partir do fim dos anos 1970 - sua experiência nas masmorras da ditadura estabelecida com o golpe de $1964 .{ }^{\mathrm{I4}}$ Por sua vez, Graciliano Ramos parecia desconhecer as memórias de presos políticos em momentos históricos anteriores, como aquelas de combatentes contra o governo de Arthur Bernardes, especialmente as de Everardo Dias e de Maurício de Lacerda, ambas de 1927. Atestava-se a dificuldade de transmitir experiências entre gerações, especialmente nos meios de esquerda. 
Há, contudo, indicadores de maior continuidade no âmbito estético, por exemplo, no cinema. Nelson Pereira dos Santos - que em I963 já havia transposto para a tela o romance Vidas secas - filmou Memórias do cárcere em I983 (Davi, 2007). Na ficção literária, Silviano Santiago escreveu Em liberdade (I98I), como se fosse um diário do próprio Graciliano logo após sair da cadeia em I937. Assim, a obra do velho Graça servia como referencial para refletir sobre a transição democrática vivida na década de ig80.

\section{CONCLUSÃO}

Nas Memórias do cárcere, Graciliano Ramos esforçava-se para não usar a primeira pessoa do singular e não ultrapassar seu suposto "tamanho ordinário", atribuindo-se importância indevida, embora admitisse que "bons propósitos" não o livravam de se revelar "com frequência egoísta e mesquinho" (Ramos, 2008: I5-I6). Tentava escapar do que pareciam ser defeitos nas memórias de Trotsky, que lhe causaram impressão lastimosa: "pimponice, egocentrismo, desonestidade", tudo que pretendia evitar (Ramos, 2008: 590). Paradoxalmente, contudo, a intenção expressa de modéstia guindava o velho Graça à grandeza do reconhecimento público. Os cuidados do escritor e a qualidade da obra não a deixaram a salvo da "ilusão biográfica", para usar o termo de Bourdieu (I998), pois foram as Memórias do cárcere que colocaram seu autor no panteão não só dos escritores, mas também da intelectualidade brasileira, particularmente a de esquerda, como vítima exemplar das arbitrariedades do primeiro governo Vargas, em que pesem as ambiguidades já registradas em relação a ele.

O saldo regenerador da experiência trágica de Graciliano pode ser encontrado no relato de seu filho Ricardo Ramos (I992: I59 e ss): longos trechos das Memórias, ainda inconclusas, eram lidos em voz alta por amigos e familiares nas habituais celebrações aos domingos na residência do mestre, que assim era homenageado em público. Ele escreveu no seu presente sobre o passado, mas indicava para o futuro. Fazia uma espécie de testamento literário, ao deixar para a História um legado de denúncia do cárcere e defesa da dignidade humana, que ao mesmo tempo lhe trouxe a distinção da consagração pública. 
Marcelo Ridenti é doutor em Sociologia pela Universidade de São Paulo (USP) e professor titular de Sociologia no Instituto de Filosofia e Ciências Humanas da Universidade Estadual de Campinas (IFCH-Unicamp). Suas áreas de interesse são as relacões entre cultura e política, a sociologia dos intelectuais e o estudo de partidos e movimentos de esquerda. É autor de Brasilidade revolucionária. Um século de cultura e política (2010), e Em busca do povo brasileiro. Artistas da revolução, do CPC à era da tv (20I4). 


\section{NOTAS}

I Este artigo é parte de uma pesquisa mais ampla sobre artistas e intelectuais comunistas, com apoio do Conselho Nacional de Desenvolvimento Científico e Tecnológico (CNPq). Uma versão mais condensada será publicada em espanhol, na Argentina, como parte da coletânea que está sendo organizada por Jorge Myers e Sergio Miceli sobre o memorialismo na América Latina. O texto enfatiza o diálogo diretamente com a obra, mas remete também à fortuna crítica, sobretudo nas notas de rodapé.

2 As observações de Sorá foram feitas no seminário internacional "A memorialística latino-americana nas humanidades", realizado na Universidade de São Paulo em 2I e 22 de outubro de 20Io, no âmbito do Projeto Temático "Formação do campo intelectual e da indústria cultural no Brasil contemporâneo", coordenado por Sergio Miceli e apoiado pela Fundação de Amparo à Pesquisa do Estado de São Paulo (FAPESP).

3 A edição atual reúne os quatro volumes num só (Ramos, 2008). Ela foi confrontada com os originais datilografados, incluindo as últimas correções do autor. Todas as próximas citações da obra referem-se a esta edição.

4 A trajetória de José Olympio foi esmiuçada nas obras de Pereira (2008) e Sorá (20I0).

5 Estas e outras informações sobre a vida do autor baseiamse em obras como a detalhada biografia escrita por Dênis de Moraes (1996), e ainda as de Valentim Facioli (I987) e de Ricardo Ramos (I992).

6 Vargas era Presidente da República em I953, ano do lançamento do livro. Fora eleito democraticamente, assumindo o posto em I95I, após afastamento da política desde o fim do Estado Novo, em I945. Viria a suicidar-se em I954 para não ser derrubado, como se sabe. Carlos Lacerda, principal inimigo de Vargas, rasgou elogios a Memórias do cárcere em seu jornal, Tribuna da Imprensa (Ramos, I992: 197).

7 Carta de Graciliano Ramos a Getúlio Vargas, 29 de agosto de I938. Folha de S. Paulo, I2.09.2010, p. Ai4.

8 As crônicas eram publicadas simultaneamente na revista portuguesa Atlântico, ligada à ditadura de Salazar. Mais tarde foram reproduzidas em Viventes da Alagoas (Ramos, I962). 
9 Por exemplo, sobre a relação entre intelectuais, classes dirigentes e Estado no período, ver o livro de Sergio Miceli e a polêmica sobre o tema no prefácio de Antonio Candido (Miceli, I979). Em estudo clássico sobre o conjunto da obra de Graciliano Ramos, Candido tratou de Memórias do cárcere, que se destacaria, sobretudo, como "documento humano" (Candido, 2006: I4).

Io Carlos Drummond de Andrade abriu sua primeira obra, Alguma poesia, de I930, com os célebres versos: "Quando nasci, um anjo torto/ desses que vivem na sombra/ disse: Vai, Carlos! Ser gauche na vida" (I974: 3).

I I Ver o uso desse verbo em Ramos (2008: I2, 408, 476, 499, entre outras).

I 2 Este e outros casos de anacronismo foram apontados, por exemplo, por Gorender (I995) e Schnaiderman (I995).

I3 Tanto que o mesmo trecho, embora visto de outros ângulos, foi destacado por intérpretes como Wander Miranda (I992: I48), em sua reflexão sobre a "função política do corpo" em Memórias do cárcere, e na ficção de Silviano Santiago inspirada nessa obra de Graciliano Ramos (Santiago, I98I).

I4 Uma bibliografia ampla sobre o tema consta em Ridenti (20I0) e Karepovs (20I2).

\section{REFERÊNCIAS BIBLIOGRÁFICAS}

Andrade, Carlos Drummond de. (1974) [1930]. Alguma poesia. In: Reunião: ro liuros de poesia. 6. ed. Rio de Janeiro: José Olympio.

Berman, Marshall. (I986). Tudo que é sólido desmancha no ar. São Paulo: Companhia das Letras.

Bomeny, Helena; Costa, Vanda \& Schwarzmann, Simon. (2000). Tempos de Capanema. 2. ed. São Paulo: Paz e Terra. Bourdieu, Pierre. (2008) [1979]. A distinção: crítica social do julgamento. São Paulo/Porto Alegre: Edusp/Zouk.

Bourdieu, Pierre. (1998). A ilusão biográfica. In: Ferreira, Marieta de Moraes \& Amado, Janaína (orgs.). Usos e abusos da história oral. 2. ed. Rio de Janeiro: Ed. FGV, p. I83-I9I. Candido, Antonio. (2006) [1956]. Ficção e confissão. Ensaios sobre Graciliano Ramos. 3. ed. revista. Rio de Janeiro: Ouro sobre Azul. 
Davi, Tânia Nunes. (2007). Subterrâneos do autoritarismo em Memórias do Cárcere. De Graciliano Ramos a Nelson Pereira dos Santos. Uberlândia: EDUFU.

Dias, Everardo. (s/d) [1927]. Bastilhas modernas. São Paulo: Empresa Editora de Obras Sociais e Literárias.

Facioli, Valentim. (1987). Um homem bruto da terra (biografia intelectual). In: Bosi, Alfredo et al. Graciliano Ramos. São Paulo: Ática, p. 23-106.

Florent, Adriana Coelho. (20II). Graciliano Ramos em seu tempo: o meio literário na era Vargas. São Paulo: Terceira Margem. Gorender, Jacob. (I995). Graciliano Ramos: lembranças tangenciais. Estudos Avançados, 23, jan-abr, p. 323-33r.

Karepovs, Dainis. (2012). Biografias de esquerda: memórias sobre a ditadura. Perseu: história, memória e política, 8/6, p. 317-357.

Lacerda. Maurício de. (I980) [1927]. História de uma covardia. 2. ed. Rio de Janeiro: Nova Fronteira.

Marx, Karl \& Engels, Friedrich. (I996) [I848]. Manifesto do Partido Comunista. 6. ed. Petrópolis: Vozes.

Marx, Karl. (1983) [1867]. O capital, vol. I, tomo I. São Paulo: Abril Cultural.

Miceli, Sergio. (1979). Intelectuais e classe dirigente no Brasil (I920-1945). São Paulo: Difel.

Miranda, Wander Melo. (I992). Corpos escritos: Graciliano Ramos e Silviano Santiago. São Paulo/Belo Horizonte: Edusp/ Ed. UFMG.

Moraes, Dênis de. (I996). O velho Graça: uma biografia de Graciliano Ramos. 3. ed. Rio de Janeiro: José Olympio.

Pereira, José Mário. (2008). José Olympio: o editor e sua casa. Rio de Janeiro: Sextante.

Ramos, Graciliano. (2008) [1945]. Infância. 39. ed. Rio de Janeiro: Record.

Ramos, Graciliano. (2008) [1953]. Memórias do cárcere. 44. ed. Rio de Janeiro: Record.

Ramos, Graciliano. (1962). Viventes da Alagoas. São Paulo: Martins Fontes.

Ramos, Graciliano. (I954). Viagem. Rio de Janeiro: José Olympio. 
Ramos, Ricardo. (1992). Graciliano: retrato fragmentado. São Paulo: Siciliano.

Ridenti, Marcelo. (20II). Jorge Amado e seus camaradas no círculo comunista internacional. Sociologia \& Antropologia, I/2, p.165-194.

Ridenti, Marcelo. (20I0). Posfácio. O fantasma da revolução brasileira. 2. ed. revista e ampliada. São Paulo: Ed. Unesp. Santiago, Silviano. (I98I). Em liberdade. Rio de Janeiro: Paz e Terra.

Schnaiderman, Boris. (I995). Duas vozes diferentes em Memórias do Cárcere? Estudos Avançados, 23, jan-abr, p. 332-337.

Sorá, Gustavo. (2010). Brasilianas: José Olympio e a gênese do mercado editorial brasileiro. São Paulo: Edusp/Com-Arte. 
Palavras-chave

Graciliano Ramos;

Memórias;

Literatura e sociedade;

Escritores comunistas;

Intelectuais e artistas

na era Vargas.
Keywords

Graciliano Ramos;

Memoirs;

Literature and society;

Communist writers;

Intellectuals and artists under Vargas' government.

\section{GRACILIANO RAMOS E SUAS}

\section{MEMÓRIAS DO CÁRCERE: CICATRIZES}

\section{Resumo}

O artigo analisa alguns aspectos do livro Memórias do cárcere, de Graciliano Ramos, publicado postumamente em I953. A experiência na cadeia em I936 significou um corte na vida do autor, que deixou o estado natal de Alagoas para nunca mais voltar, estabelecendo-se no Rio de Janeiro. A obra é uma espécie de testamento literário no qual ele registrou seu intento de ser recordado como uma pedra no caminho das classes dominantes - com as quais, entretanto, teve relações ambíguas. Ao recordar o cárcere, Graciliano externou seu mal-estar com a ordem estabelecida, que colocava ainda obstáculos à profissionalização e autonomia dos escritores, ao mesmo tempo que lhes oferecia relativos privilégios. Paradoxalmente, a intenção expressa nas Memórias do cárcere de registrar as arbitrariedades praticadas na cadeia também serviu como elemento de distinção, guindando o autor ao pleno reconhecimento público como escritor e exemplo de intelectual vitimado pelo autoritarismo, embora depois de solto tenha ocupado cargos ligados ao governo federal.

\section{GRACILIANO RAMOS AND HIS}

\section{MEMÓRIAS DO CÁRCERE: THE SCARS OF HISTORY}

\section{Abstract}

The article discusses the book by Graciliano Ramos Memórias do cárcere (Memoirs of prison), posthumously published in 1953. His experience in jail in 1936 meant a cut in the life of the author, who left the home state of Alagoas, never to return, settling in Rio de Janeiro. The book is a kind of literary testament in which he registered his intent to be remembered as a stone in the path of the ruling classes - with which, however, he had ambiguous relations. By recalling the prison Graciliano expressed his unease with the established order, which also placed obstacles to the professionalization and autonomy of the writers, but at the same time it offered them certain privileges. Paradoxically, the explicit intention of registering the arbitrariness suffered in jail also served as an element of distinction and led the author to full public recognition as a writer and an example of intellectual victimized by authoritarianism, although he held positions related to the federal government after his release. 